\title{
Systematic Review of Peer-Reviewed Literature on Global Condom Promotion Programs
}

\author{
William D. Evans ${ }^{1, * \mathbb{C}}$, Alec Ulasevich ${ }^{2}$, Megan Hatheway ${ }^{1}$ and Bidia Deperthes ${ }^{3}$ \\ 1 Milken Institute School of Public Health and The George Washington University, \\ Washington, DC 20052, USA; mjhatheway@gwmail.gwu.edu \\ 2 Independent Consultant, Silver Spring, MD 20902, USA; alec.ulasevich@gmail.com \\ 3 United Nations Family Planning Agency, New York, NY 10017, USA; deperthes@unfpa.org \\ * Correspondence: wdevans@gwu.edu
}

Received: 18 February 2020; Accepted: 25 March 2020; Published: 27 March 2020

\begin{abstract}
Background: Globally, 1.7 million people were newly infected with HIV in 2018. Condoms are inexpensive, cost-effective, reduce HIV/STI incidence, morbidity, mortality, and unintended pregnancies, and result in health care cost savings. Given the rapid increase in at-risk adolescent and young adult (AYA) populations in countries with high HIV/STI prevalence as well as the reductions in donor support, promoting consistent condom use remains crucial. We synthesized all peer-reviewed literature on condom promotion programs with a focus on promotion in low and lower middle income (LMIC) countries and with AYA users. Methods: We systematically reviewed the published literature. Following Preferred Reporting Items for Systematic Reviews and Meta-Analyses (PRISMA) methods, we identified 99 articles published between 2000-2019. Results: Condom promotion programs were generally effective in changing attitudes, social norms, and beliefs in favor of condom use, and 85\% demonstrated positive effects on multiple condom use measures. Programs targeting AYA were at least equally as effective as those targeting others and often showed greater use of best practices, such as mass media (66\%) and audience segmentation (31\%). We also saw differences between programs in the intervention strategies they used and found greater effects of marketing strategies on AYA compared to the overall sample. Conclusion: Condoms remain essential to prevention, and donor support must be maintained to combat the HIV/STI epidemic.
\end{abstract}

Keywords: HIV/STI; condoms; promotion; communication; social marketing

\section{Introduction}

Despite gains made in the prevention of HIV and the scaling up of treatment programs, incidence is still alarmingly high in some settings. The recent Evidence for Contraceptive Options and HIV Outcomes (ECHO) study, for example, found an incidence rate of $3.8 \%$ among young women in select study sites [1]. Globally, an estimated 1.7 million people were newly infected in 2018, with an unmet need for contraception of some 214 million individuals and 357 million cases of curable sexually transmitted infections (STIs) [2]. While data (up to 2016) show slow but steady progress toward higher levels of condom use among non-marital, non-cohabitating men and sex workers, countries fall short of global targets (some by a substantial amount), inequities remain, and condom use in younger populations shows signs of stagnation or decline in at least a few key countries [3]. Donor funding for condom programs is also a concern; global investments in HIV prevention have declined $44 \%$ since 2012 [4]. Intensified efforts are urgently needed to increase condom use, especially in high HIV/STI prevalence countries.

Condoms are inexpensive and cost-effective. They reduce HIV and STI incidence, morbidity, mortality, and unintended pregnancies and result in cost savings for healthcare and social sectors. 
Condoms are highly effective in preventing sexual transmission of HIV. Consistent and correct use of the male condom significantly reduces HIV transmission during vaginal sex (80\%) [5] and anal sex $(70-90 \%)$ [6,7]. Female condoms can provide similar levels of protection for vaginal sex and anal sex (although less data are available on their use during anal sex), making them among the most effective prevention technologies available today [8].

Condoms are also a familiar and convenient prevention method to most people and are, for many, still the only viable option to prevent HIV, STIs, and unintended pregnancies. Condoms are a user-initiated method, are easy to use and store, do not require medical prescriptions or direct provision by health-care personnel or in facilities, and can be used by anyone who is sexually active-including youth. Condom programming is one of five core UNAIDS Prevention Pillars [9] and should be an integrated component of all HIV prevention and care packages, offering individuals at risk with an important and effective choice to prevent HIV, STIs, and unintended pregnancies.

The current study has two overarching aims: (1) to analyze the literature in order to demonstrate which condom promotion programs have been shown to be effective and their characteristics; (2) to provide an overall description of published condom programs worldwide. We address these aims in the context of the current environment for condom demand creation and donor-sponsored programs.

Strong condom programming requires investment at the systems level in program stewardship, which will support improvements in demand and supply, leading to improved program outcomes. Mann Global Health, in close collaboration with the United Nations Family Planning Agency (UNFPA), UNAIDS, and the Bill and Melinda Gates Foundation (BMGF), has developed a theory of change for this systems level approach, as shown in Figure 1 [10].



Figure 1. The Condom Program Pathway, a theory of change.

Program stewardship is a critical function for every nationally-owned condom program to develop and implement strategies to increase use sustainably. The components of program stewardship-leadership and coordination that stretch across all sectors engaged in condom programming (public, non-profit organizations (NGO), and commercial); production and dissemination of program analytics to inform intervention design and monitor progress; financing to support needed interventions; and a supportive policy and regulatory environment-are all prerequisites for success. In particular, investments in strengthening leadership and coordination and program analytics are urgently needed in many countries. These investments at the systems level will improve quantification of need and understanding of existing use and create a strong evidence base to understand supply and demand dynamics that influence uptake and use [11]. National condom programs also require efforts to develop a supportive environment, including improved coordination and advocacy in support of a total market approach (TMA) that engages all sectors and enabling policy and regulatory environments that support diversified markets to ensure condom access is sustained. Additionally, the role of pre-exposure prophylaxis (PrEP) and the possibility that it is associated with reduced condom use, potentially leading to increased STI rates, needs to be explored as part of comprehensive condom promotion policies [12].

Given the landscape of current condom programming, there is a need to understand the state of evidence for condoms as an HIV/STI prevention strategy and an effective contraceptive method, especially for young people, as well as gaps in the knowledge base and the potential for future programs and research to move the field forward. In particular, the use of a total market approach 
(TMA) (i.e., creating a healthy market in which consumers who are able to pay purchase condoms, and efficient distribution ensures the poor have access to free product) is critical to the future of condom marketing [13,14].

The need for effective application of TMA is even greater given the rapid growth in the population of adolescents and young adults (AYA) in regions most affected by HIV/STI, including sub-Saharan Africa (SSA). AYA populations in SSA are estimated to increase to some 250 million under age 25 by 2030, and, given their potential sexual risk taking behavior, the HIV/STI epidemic remains a public health priority calling for comprehensive and innovative solutions [15].

Thus, there is a need to document and systematically review the state of evidence on condom programs with a specific focus on effectiveness of interventions to promote condom use through communication and social marketing, which have been the primary demand creation strategies used to date. The current research provides evidence and a framework for future programing to support TMA programs.

Overall goals of this study are to systematically review all published literature on outcomes of condom distribution programs worldwide. One important part of this project is to understand the demand generation strategies in low and lower middle income (LMIC) countries and to understand the AYA generation of condom users in order to develop effective demand promotion strategies. We hypothesize (H1) that demand generation efforts have been effective in increasing determinants of condom use, and (H2) that demand generation has been effective in increasing sales and distribution of condoms. We also ask the research question (RQ1) of whether these efforts have been more effective among specific population groups, in specific geographic locations or settings, and based on specific media channels and strategies.

In particular, we ask whether these efforts have been more effective among AYA ages 15-34 during the period in the which the project/study was conducted. Given the rapid growth of the AYA population in regions such as SSA, understanding how best to promote condoms to this priority population is critical to future prevention efforts.

\section{Methods}

We conducted a systematic search of the published, peer-reviewed literature using all relevant major online research literature databases (specified below) and following widely accepted methods for systematic review (Higgins and Green, 2011) [16]. We note that social marketing and interventions focused on condoms are also widely represented in unpublished reports and other "gray" literature. However, in this study, we focused on peer-reviewed literature in order to ensure quality of evidence and consistency with accepted systematic review practices.

We identified as relevant any manuscripts published in the English language in health, social science, and business literature that used at least one of the four Ps of marketing, had a behavioral objective targeting promotion of condom sales, use, and related behaviors, and had a health objective targeting HIV/STI or related disease prevention. We based the review methodology in part on methodologies from a previous review of branded social marketing campaigns conducted by the lead author [17]. Specifically, we searched the following health, social science, and business databases: PubMed, PsycINFO, Web of Science (includes Science Citation Index Expanded, Social Sciences Citation Index, and Arts and Humanities Citation Index), Communication \& Mass Media Complete, Academic Search Premier, Business Source Premier, CINAHL, Health Source: Nursing/Academic Edition, and Health Source: Consumer Edition.

We selected search terms based on the authors' experiences in the field and conducting previous reviews and in consultation with a medical research librarian. We applied the following criteria to conduct the search: (1) limited to only include articles published from 2000 onward; (2) search terms included condoms + marketing, brands, branding, health promotion, free distribution, commercial, subsidized; (3) went beyond other recent reviews (e.g., Evans et al., 2015) to include distribution programs for commercial brands (to extent any published results) [17]; coding included population 
targeted, marketing methods, research/evaluation methods, outcomes (including differential effects on audiences), type of condom (male/female), country/region, urban/peri-urban/rural, and age range target (adolescents, young adults, older).

For completeness, we also searched literature known to the authors, including publications on condom promotion, social marketing, and related intervention studies in low and middle income countries. In particular, the bibliographies of two recent meta-analyses on social marketing and mass media intervention were reviewed, and potential citations were screened following the methods described [18-20].

We searched all sources listed above in the date range of January 2000 to December 2019. Based on this process, we created a database of all 4240 unduplicated articles on social marketing interventions regarding condoms. Based on abstract review, we immediately excluded 3988 articles that did not relate to condom promotion or marketing, were clearly not original research, or were only focused on other family planning methods, leaving 252.

Next, we obtained and reviewed the 252 full-text articles based on our specific criteria for inclusion in study. Namely, we screened them for reports on interventions that: (1) were original research (not review papers, meta-analyses, or commentaries); (2) utilized some form of social marketing principles (i.e., reported on use of one or more of the four Ps); (3) targeted behavior relating to condom use; and (4) targeted HIV/STI prevention and/or related reproductive health outcomes as a health objective. We also screened to ensure the articles included specific reports of evaluation or implementation of social marketing activities, defined as coordinated efforts to promote, distribute, or use pricing strategies to encourage adoption of various products aimed primarily at HIV/STI prevention. Based on this in-depth screening process, we excluded 153 articles and identified 99 articles for inclusion in the study. Figure 2 summarizes the review process based on Preferred Reporting Items for Systematic Reviews and Meta-Analyses (PRISMA) methodology [21]. In this review, we followed the complete 27-item PRISMA checklist previously published [21].

Note that, due to the diverse nature of the literature on demand creation and marketing interventions in this area and the varying methods of reporting outcomes, we chose not to attempt a meta-analysis of effects of reviewed interventions on behavior. Rather, the purpose of this paper is to describe the nature of the interventions and literature, hopefully promoting more uniform reporting of condom promotion outcomes in the future.

Once the review sample of articles was identified, the first two authors individually read each of the articles in-depth and coded them for specific content reported in the results section. The results of all reviews were compiled and discussed by the reviewers. Potential sources of differences in assumptions and approaches in coding articles were identified and discussed. A consensus was reached about coding, and common procedures were adopted where discrepancies were identified.

\section{Results}

Table 1 provides a summary of basic information gleaned from each condom promotion article reviewed. The articles dealt with interventions relating to social marketing and promotion of condom brands, HIV/STI prevention programs based on increasing condom use, and family planning programs that promoted condoms. The majority of studies ( $81 \%$ ) were focused only on male condoms, but $19 \%$ included female condoms in some fashion.

Fifty-five percent (55\%) of studies were published before 2010. The majority of studies were conducted in low and middle income countries, mostly in South Asia and Sub Saharan Africa (54), with some reported in wealthy countries, mainly the USA (27). Finally, the largest single age range targeted was AYA age 15-34 (35\%), followed by women (31\%). Eleven percent of studies specifically targeted LGBTQ populations. 


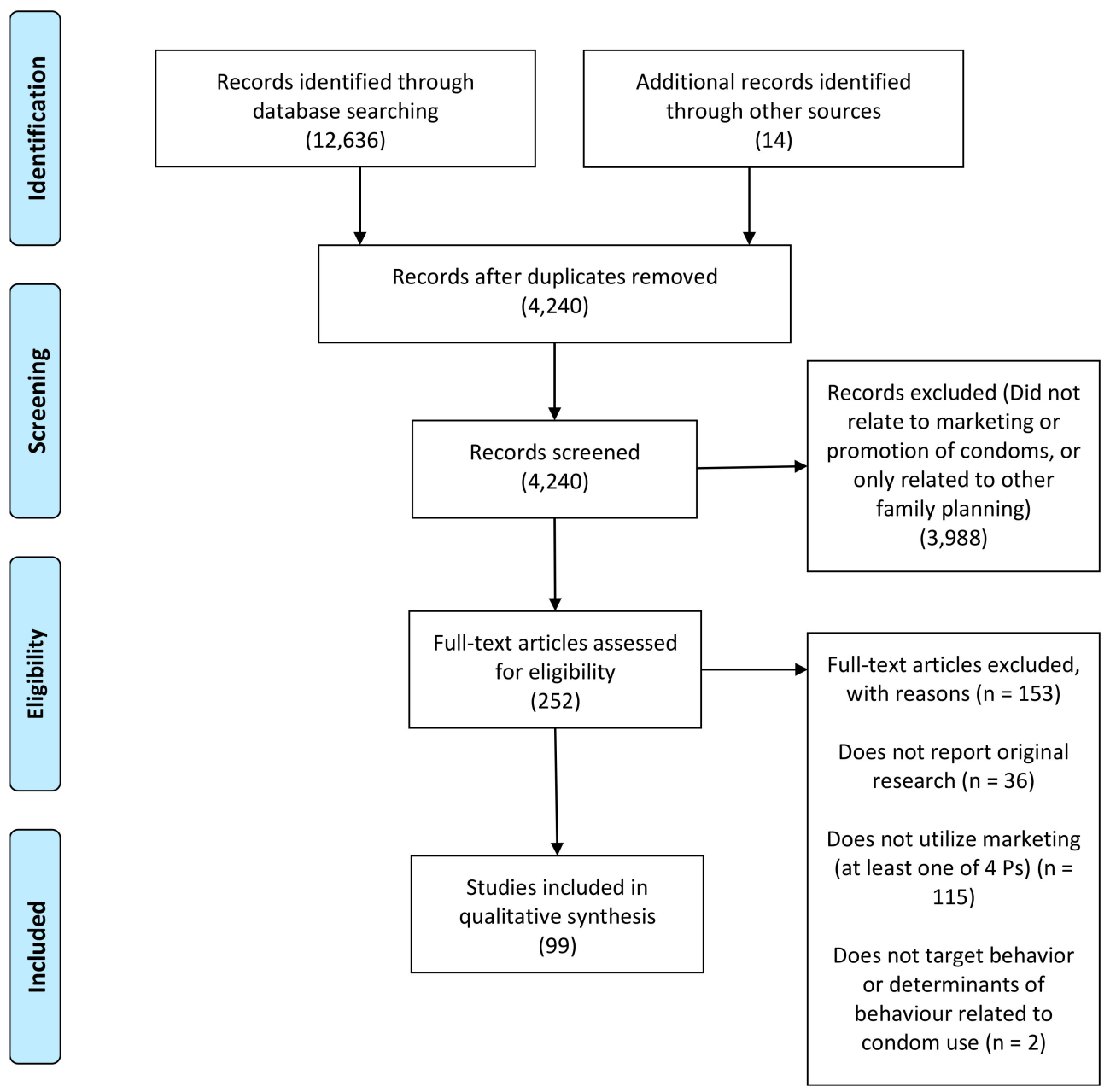

Figure 2. Preferred Reporting Items for Systematic Reviews and Meta-Analyses (PRISMA) diagram of systematic review process.

Table 1. Characteristics of the publications reviewed.

\begin{tabular}{ccccccc}
\hline & \multicolumn{2}{c}{ Overall } & \multicolumn{2}{c}{ AYA Population } & \multicolumn{2}{c}{ Other Populations } \\
\hline Product Promoted & $\mathbf{N}$ & Percent & $\mathbf{N}$ & Percent & $\mathbf{N}$ & Percent \\
Male Condom & 80 & $81 \%$ & 30 & $86 \%$ & 50 & $78 \%$ \\
Female Condom & 9 & $9 \%$ & 2 & $6 \%$ & 7 & $11 \%$ \\
Both & 10 & $10 \%$ & 3 & $9 \%$ & 7 & $11 \%$ \\
\hline Year of Publication & $\mathbf{N}$ & Percent & $\mathbf{N}$ & Percent & $\mathbf{N}$ & Percent \\
2000 to 2009 & 45 & $45 \%$ & 20 & $57 \%$ & 25 & $39 \%$ \\
2010 to 2019 & 54 & $55 \%$ & 15 & $43 \%$ & 39 & $61 \%$ \\
\hline Region & $\mathbf{N}$ & Percent & $\mathbf{N}$ & Percent & $\mathbf{N}$ & Percent \\
Sub-Sahara African & 38 & $38 \%$ & 10 & $29 \%$ & 28 & $44 \%$ \\
US/Canada & 27 & $27 \%$ & 14 & $40 \%$ & 13 & $20 \%$ \\
India & 8 & $8 \%$ & 0 & $0 \%$ & 8 & $13 \%$ \\
Latin America & 7 & $7 \%$ & 2 & $6 \%$ & 5 & $8 \%$ \\
Western Europe & 5 & $5 \%$ & 3 & $9 \%$ & 2 & $3 \%$ \\
South East Asia & 5 & $5 \%$ & 3 & $9 \%$ & 2 & $3 \%$ \\
East Asia & 4 & $4 \%$ & 1 & $3 \%$ & 3 & $5 \%$ \\
India sub-continent & 2 & $2 \%$ & 0 & $0 \%$ & 2 & $3 \%$ \\
Oceania & 4 & $4 \%$ & 4 & $11 \%$ & 0 & $0 \%$ \\
Central Asia & 1 & $1 \%$ & 0 & $0 \%$ & 1 & $2 \%$ \\
Eastern/Southern Europe & 0 & $0 \%$ & 0 & $0 \%$ & 0 & $0 \%$ \\
Middle East and North Africa & 0 & $0 \%$ & 0 & $0 \%$ & 0 & $0 \%$ \\
\hline
\end{tabular}


For each characteristic listed in the left-hand column, Table 1 shows the total for the overall sample (all publications reviewed), the subset for each category in the AYA population, and the subset for other populations, defined as those that did not specifically target AYA (i.e., either explicitly targeted those age 35 and older or reported no specific age targeting).

A higher percentage of articles in the 2000s reported targeting the AYA population (57\%) compared to the overall population ( $45 \%$ ), and the reverse was true in the 2010 s (55\% overall compared to $43 \%$ targeting AYA). Thirty-eight percent of efforts in Sub-Saharan African targeted the overall sample compared to $29 \%$ that targeted AYAs. However, $40 \%$ of efforts in the US/Canada targeted AYAs compared to $27 \%$ for this region in the overall sample.

As shown in Table 2, the interventions used a wide range of health communication and social marketing strategies, including mass media, interpersonal communication (IPC) through community outreach, and visits to households by health workers. High levels of awareness of the promoted health messages were reported. Among these, slightly more than half of studies reviewed (52\%) reported use of mass media channels, with community outreach being the second most commonly reported technique $(44 \%)$. Techniques to reach specific audiences were reported with segmentation being most common (21\%), but in some cases, articles did not provide sufficient information to code for these categories.

Table 2. Marketing approaches.

\begin{tabular}{|c|c|c|c|c|c|c|}
\hline \multirow[t]{2}{*}{ Marketing Channels } & \multicolumn{2}{|c|}{ Overall } & \multicolumn{2}{|c|}{ AYA Population } & \multicolumn{2}{|c|}{ Other Populations } \\
\hline & $\mathrm{N}$ & Percent & $\mathrm{N}$ & Percent & $\mathrm{N}$ & Percent \\
\hline Reported channels of dissemination & 74 & $75 \%$ & 25 & $71 \%$ & 49 & $77 \%$ \\
\hline Reported mass media channels & 51 & $52 \%$ & 23 & $66 \%$ & 28 & $44 \%$ \\
\hline \multicolumn{7}{|l|}{ Mass media channels mentioned } \\
\hline TV & 19 & $19 \%$ & 9 & $26 \%$ & 10 & $16 \%$ \\
\hline Radio & 33 & $33 \%$ & 14 & $40 \%$ & 19 & $30 \%$ \\
\hline Print & 22 & $22 \%$ & 11 & $31 \%$ & 11 & $17 \%$ \\
\hline Outdoor & 32 & $32 \%$ & 13 & $37 \%$ & 19 & $30 \%$ \\
\hline Digital & 7 & $7 \%$ & 3 & $9 \%$ & 4 & $6 \%$ \\
\hline Point of Sale/Location & 16 & $16 \%$ & 9 & $26 \%$ & 7 & $11 \%$ \\
\hline Other & 1 & $1 \%$ & 0 & $0 \%$ & 1 & $2 \%$ \\
\hline \multicolumn{7}{|l|}{ Other dissemination channels } \\
\hline Earned Media & 2 & $2 \%$ & 1 & $3 \%$ & 1 & $2 \%$ \\
\hline Community Outreach & 44 & $44 \%$ & 16 & $46 \%$ & 28 & $44 \%$ \\
\hline Community Mobilization & 15 & $15 \%$ & 6 & $17 \%$ & 9 & $14 \%$ \\
\hline Health Care Providers & 25 & $25 \%$ & 8 & $23 \%$ & 17 & $27 \%$ \\
\hline Mobile & 2 & $2 \%$ & 1 & $3 \%$ & 1 & $2 \%$ \\
\hline Social Media & 4 & $4 \%$ & 1 & $3 \%$ & 3 & $5 \%$ \\
\hline Other & 4 & $4 \%$ & 2 & $6 \%$ & 2 & $3 \%$ \\
\hline \multicolumn{7}{|l|}{ Other Marketing Techniques } \\
\hline Audience Segmentation & 21 & $21 \%$ & 11 & $31 \%$ & 10 & $16 \%$ \\
\hline Message Tailoring & 10 & $10 \%$ & 6 & $17 \%$ & 4 & $6 \%$ \\
\hline Educational Entertainment & 9 & $9 \%$ & 5 & $14 \%$ & 4 & $6 \%$ \\
\hline Other & 7 & $7 \%$ & 3 & $9 \%$ & 4 & $6 \%$ \\
\hline
\end{tabular}

AYA: adolescent and young adult.

There were some differences observed between AYA-targeted marketing and overall. Sixty-six percent of AYA marketing used mass media compared to $52 \%$ of the overall sample. The largest difference in mass media channel reported was $26 \%$ for AYA point of sale/location marketing efforts compared to $16 \%$ in the overall sample for that category. Among other marketing techniques reported, $31 \%$ of AYA efforts used audience segmentation (considered widely to be best marketing practice [22]) compared to $21 \%$ of the overall sample. 
Table 3 provides a summary of the social marketing development described in the condom promotion articles reviewed. Forty-two percent $(42 \%)$ of the studies described specific scientific theories used in the development of the social marketing effort used. Psychological theories were the most commonly used theories, found in $29 \%$ of the studies reviewed, followed by marketing theory with $19 \%$. One third of the articles (33\%) described intervention efforts based in formative research such as interviews and focus groups.

Table 3. Marketing development.

\begin{tabular}{ccccccc}
\hline \multirow{2}{*}{ Coding Category } & \multicolumn{2}{c}{ Overall } & Youth and Young Adults & \multicolumn{2}{c}{ Other Populations } \\
\cline { 2 - 7 } & $\mathbf{N}$ & Percent & $\mathbf{N}$ & Percent & $\mathbf{N}$ & Percent \\
\hline Scientific Theory Mentioned & 42 & $42 \%$ & 22 & $63 \%$ & 20 & $31 \%$ \\
\hline Type of Theory Mentioned & & & & & & \\
Psychological & 29 & $29 \%$ & 16 & $46 \%$ & 13 & $20 \%$ \\
Communication & 5 & $5 \%$ & 3 & $9 \%$ & 2 & $3 \%$ \\
Marketing & 19 & $19 \%$ & 7 & $20 \%$ & 12 & $19 \%$ \\
Other & 1 & $1 \%$ & 0 & $0 \%$ & 1 & $2 \%$ \\
Formative Research Mentioned & 33 & $33 \%$ & 18 & $51 \%$ & 15 & $23 \%$ \\
\hline Type of Formative Research Mentioned & & & & & & \\
Focus Groups & 13 & $13 \%$ & 8 & $23 \%$ & 5 & $8 \%$ \\
Individual Interviews & 7 & $7 \%$ & 3 & $9 \%$ & 4 & $6 \%$ \\
Quantitative Research & 7 & $7 \%$ & 3 & $9 \%$ & 4 & $6 \%$ \\
Other & 4 & $4 \%$ & 4 & $11 \%$ & 0 & $0 \%$ \\
\hline Marketing P's & & & & & & \\
Product & 66 & $67 \%$ & 22 & $63 \%$ & 44 & $69 \%$ \\
Price & 49 & $49 \%$ & 19 & $54 \%$ & 30 & $47 \%$ \\
Place & 74 & $75 \%$ & 26 & $74 \%$ & 48 & $75 \%$ \\
Promotion & 82 & $83 \%$ & 26 & $74 \%$ & 56 & $88 \%$ \\
\hline
\end{tabular}

Higher percentages of efforts targeting AYA used theory, with 63\% reporting some kind of theoretical framework, driven mainly by greater use of psychological theory $(46 \%$ for AYA efforts compared to $29 \%$ for the overall sample). Fifty-one percent of AYA efforts reported formative research in the marketing effort compared to $33 \%$ in the overall sample, with higher percentages reported for the AYA efforts in each category of formative research methods.

Examination of the studies in terms of the use of the four Ps of marketing (place, price, product, and promotion) revealed that $45 \%$ used all four marketing techniques [22]. Promotion was the most commonly used technique reported by $83 \%$ of the articles, as represented by the channels shown in Table 2. The interventions that addressed place included any efforts to expand availability of condoms, such as community based sales, distribution of condoms by community health workers and health workers, as well as assuring availability of condoms in non-conventional venues such as hotels and places of entertainment. Three quarters of the studies reviewed $(75 \%)$ mentioned such efforts to expand availability of condoms. Product interventions employed by $67 \%$ of the articles represented a wide range of techniques, from introducing new product such as female condom, introducing flavored condoms, improving existing products and packaging, to re-positioning condoms as birth control rather than STI prevention methods in some markets. Interventions focusing on price were reported by just under half ( $49 \%$ ) of the studies. These included efforts to both reduce the actual cost of condoms through subsidies as well as to decrease the psychological price of using condoms with regular partners.

Table 4 provides a summary of the study design and outcomes in the condom promotion articles reviewed. Most of the articles reviewed described studies with an observational design; the remaining studies were equally split between experimental and quasi-experimental designs. Almost all articles reported on the study sample size and sample characteristics. Multivariate analysis was used to report statistics in over half of the studies. More than half of the studies (57\%) aimed to assess 
condom use behavioral objectives (i.e., the effort aimed to achieve such as outcome), including condom use at last sex, consistent condom use, and condom use with specific types of partners, and clearly stated these outcomes. A similar number of articles (56\%) made clear statements about the assessing pre-behavioral objectives (i.e., the effort aimed to achieve such as outcome), including attitudes, social norms and beliefs about condom use, its benefits, acceptability, and personal preferences related to use. Correspondingly, $67 \%$ of the articles reported actually achieving some type of condom use behavioral outcome and $68 \%$ of the articles reported achieving some type of pre-behavioral outcome, as defined.

Table 4. Study design and outcomes.

\begin{tabular}{ccccccc}
\hline Coding Category & \multicolumn{2}{c}{ Overall } & AYA Population & Other Populations \\
\cline { 2 - 7 } & $\mathbf{N}$ & Percent & $\mathbf{N}$ & Percent & $\mathbf{N}$ & Percent \\
\hline Described Sample & 81 & $82 \%$ & 28 & $80 \%$ & 53 & $83 \%$ \\
Describe Sample Size & 76 & $77 \%$ & 25 & $71 \%$ & 51 & $80 \%$ \\
Describe Sample Characteristics & 69 & $70 \%$ & 23 & $66 \%$ & 46 & $72 \%$ \\
Reported Response Rate & 18 & $18 \%$ & 7 & $20 \%$ & 11 & $17 \%$ \\
\hline Research Design & & & & & & \\
Not Reported & 4 & $4 \%$ & 2 & $6 \%$ & 2 & $3 \%$ \\
Experimental & 23 & $23 \%$ & 10 & $29 \%$ & 13 & $20 \%$ \\
Quasi-Experimental & 16 & $16 \%$ & 5 & $14 \%$ & 11 & $17 \%$ \\
Observational & 56 & $57 \%$ & 18 & $51 \%$ & 38 & $59 \%$ \\
\hline Statistics Reported & & & & & & \\
Not Reported & 6 & $6 \%$ & 4 & $11 \%$ & 2 & $3 \%$ \\
Descriptive & 35 & $35 \%$ & 12 & $34 \%$ & 23 & $36 \%$ \\
Multivariate & 57 & $58 \%$ & 19 & $54 \%$ & 38 & $59 \%$ \\
Path Analysis & 1 & $1 \%$ & 0 & $0 \%$ & 1 & $2 \%$ \\
\hline Stated Objectives & & & & & & \\
\hline Product/Awareness or Reaction & 42 & $42 \%$ & 21 & $60 \%$ & 21 & $33 \%$ \\
Condom Use Pre-Behavioral Objectives & 55 & $56 \%$ & 24 & $69 \%$ & 31 & $48 \%$ \\
Condom Use Behavioral Objectives & 56 & $57 \%$ & 23 & $66 \%$ & 33 & $52 \%$ \\
Sales/Distribution & 13 & $13 \%$ & 1 & $3 \%$ & 12 & $19 \%$ \\
\hline Outcomes Reported & & & & & & $34 \%$ \\
Product/Awareness or Reaction & 52 & $53 \%$ & 18 & $51 \%$ & $34 \%$ & $53 \%$ \\
Condom Use Pre-Behavioral Outcomes & 67 & $68 \%$ & 28 & $80 \%$ & 39 & $61 \%$ \\
Condom Use Behavioral Outcomes & 66 & $67 \%$ & 25 & $71 \%$ & 41 & $64 \%$ \\
\hline Sales/Distribution & 24 & $24 \%$ & 5 & $14 \%$ & 19 & $30 \%$ \\
\hline
\end{tabular}

There were only small differences in the observed reporting of sample characteristics, research design type, and statistics between the overall and the AYA targeted efforts. However, higher percentages of AYA targeted efforts reported pre-behavioral and behavioral objectives $(69 \%$ and $66 \%$, respectively) compared to the overall sample ( $56 \%$ and $57 \%$ respectively). Thirteen percent of the overall sample reported targeting sales/distribution objectives compared to only $3 \%$ of AYA efforts. Similarly, higher percentages of AYA efforts reported achieving condom use behavior outcomes $(80 \%$ and $71 \%$, respectively) compared to the overall sample (68\% and $67 \%$, respectively), and again more of the overall sample targeted sales distribution (24\%) than AYA efforts $(14 \%)$.

Table 5 summarizes the significant findings reported by the articles reviewed, both overall and by the marketing approaches used. Overall, a higher percentage of the overall sample reported significant effects on condom awareness or positive reactions to promotions and sales/distribution $(37 \%$ and $23 \%$, respectively) compared to efforts targeting AYA ( $26 \%$ and $14 \%$, respectively). However, a higher percentage of efforts targeting AYA reported achieving condom use pre-behavioral outcomes $(71 \%)$ compared to the overall sample (58\%). 
Table 5. Significant effects reported.

\begin{tabular}{ccccccc}
\hline \multirow{2}{*}{ Coding Category } & \multicolumn{2}{c}{ Overall } & \multicolumn{2}{c}{ Youth and Young Adults } & \multicolumn{2}{c}{ Other Populations } \\
\cline { 2 - 7 } & $\mathbf{N}$ & Percent & $\mathbf{N}$ & Percent & N & Percent \\
\hline Product/Awareness or Reaction & 37 & $37 \%$ & 9 & $26 \%$ & 28 & $44 \%$ \\
Condom Use Pre-Behavioral Outcomes & 57 & $58 \%$ & 25 & $71 \%$ & 32 & $50 \%$ \\
Condom Use Behavioral Outcomes & 56 & $57 \%$ & 19 & $54 \%$ & 37 & $58 \%$ \\
Sales/Distribution & 23 & $23 \%$ & 5 & $14 \%$ & 18 & $28 \%$ \\
\hline
\end{tabular}

Next, we analyzed the significant effects data by publications that reported capturing each outcome data category. Table 6 presents the success ratio of significant findings over the studies that reported measuring each specific outcome (i.e., the proportion of articles that reported significant findings for a particular outcome variable over the number of articles that assessed that variable), both overall and by specific intervention characteristics, such as media channels, use of theory, and marketing Ps used. Overall, almost all articles (96\%) that assessed sales or distribution of condoms reported significant increase in this measure. Most articles assessed condom use pre-behavioral (attitudes, social norms, and beliefs about condom use) and condom use behavioral outcomes (use overall, frequency, and with specific partner types), and $85 \%$ each reported significant increases.

Analyzed as a ratio, we continued to see higher significant effects on awareness and reactions to promotions among the overall sample (71\%) compared to AYA efforts (50\%). However, we saw only small differences in effects for pre-behavioral outcomes and sales/distribution but a higher percentage of the overall sample demonstrating condom use outcomes (85\%) compared to the AYA efforts (76\%). Despite these differences, it should be noted that, with the exception of awareness/reactions effects among AYA efforts (50\%), all the findings for significant effects among studies that measured specific outcomes were generally high (greater than $70 \%$ and most above $85 \%$ ), indicating that, when condom use marketing targets these outcomes of interest, the efforts are mostly effective.

In terms of intervention characteristics, there were relatively few differences in terms of the intermediate outcomes. One notable difference was that $90 \%$ of interventions using mass media (51 in total) reported significant effects on attitudes, beliefs, and intentions to use condoms, and the same percentage was displayed among programs for AYA (23 in total).

In terms of behavioral outcomes, we saw a similar pattern of consistent effects between intervention categories, but the effects on AYA condom use were somewhat lower (72\% compared to $86 \%$ for other populations) for those using mass media.

Awareness outcomes were consistently lower overall and lower among AYA compared to the general sample and the other populations. These results were consistent across all intervention characteristics.

Finally, the effects of condom promotion programs on sales were generally higher among AYA compared to the overall sample and other populations across most intervention characteristics. Across the marketing Ps, all AYA focused programs showed significant effects and were consistently higher than the overall sample and other populations, suggesting that marketing strategies were especially effective in encouraging condom purchases among AYA.

In a Supplementary Material to this article, Table S1 provides an overall summary of the 99 articles that underwent full text review (references provided at the end of this manuscript). The appendix table lists the study, the population targeted, the location, the product promoted, the marketing and intervention components applied, and the research design and significant effects observed. 
Table 6. Outcomes by intervention characteristics.

\begin{tabular}{|c|c|c|c|c|c|c|c|c|c|}
\hline \multirow[b]{3}{*}{ Coding category } & \multicolumn{6}{|c|}{ Intermediate outcomes by Intervention Characteristics } & & & \\
\hline & \multicolumn{3}{|c|}{ Overall } & \multicolumn{3}{|c|}{ Youth and Young Adults } & \multicolumn{3}{|c|}{ Other Populations } \\
\hline & $\mathbf{N}$ & $\begin{array}{c}\text { Percent Reported } \\
\text { Outcome }\end{array}$ & $\begin{array}{c}\text { Percent } \\
\text { Significant Effect }\end{array}$ & $\mathbf{N}$ & $\begin{array}{l}\text { Percent Reported } \\
\text { Outcome }\end{array}$ & $\begin{array}{c}\text { Percent } \\
\text { Significant Effect }\end{array}$ & $\mathbf{N}$ & $\begin{array}{l}\text { Percent Reported } \\
\text { Outcome }\end{array}$ & $\begin{array}{c}\text { Percent } \\
\text { Significant Effect }\end{array}$ \\
\hline \multicolumn{10}{|l|}{ Product Promoted } \\
\hline Male Condom & 80 & $71 \%$ & $86 \%$ & 30 & $87 \%$ & $89 \%$ & 50 & $62 \%$ & $84 \%$ \\
\hline Female Condom & 9 & $56 \%$ & $60 \%$ & 2 & $50 \%$ & $100 \%$ & 7 & $57 \%$ & $50 \%$ \\
\hline Both & 10 & $50 \%$ & $60 \%$ & 3 & $33 \%$ & $0 \%$ & 7 & $57 \%$ & $75 \%$ \\
\hline \multicolumn{10}{|l|}{ Year of Publication } \\
\hline 2000 to 2009 & 45 & $69 \%$ & $87 \%$ & 20 & $80 \%$ & $88 \%$ & 25 & $60 \%$ & $87 \%$ \\
\hline 2010 to 2019 & 54 & $67 \%$ & $78 \%$ & 15 & $80 \%$ & $83 \%$ & 39 & $62 \%$ & $75 \%$ \\
\hline Reported Mass Media Channels & 51 & $78 \%$ & $90 \%$ & 23 & $83 \%$ & $90 \%$ & 28 & $75 \%$ & $91 \%$ \\
\hline Scientific Theory Mentioned & 42 & $86 \%$ & $86 \%$ & 22 & $91 \%$ & $85 \%$ & 20 & $80 \%$ & $88 \%$ \\
\hline Formative Research Mentioned & 33 & $70 \%$ & $70 \%$ & 18 & $67 \%$ & $67 \%$ & 15 & $73 \%$ & $73 \%$ \\
\hline \multicolumn{10}{|l|}{ Marketing P's } \\
\hline Product & 66 & $70 \%$ & $80 \%$ & 22 & $82 \%$ & $78 \%$ & 44 & $64 \%$ & $82 \%$ \\
\hline Price & 49 & $76 \%$ & $81 \%$ & 19 & $79 \%$ & $73 \%$ & 30 & $73 \%$ & $86 \%$ \\
\hline Place & 74 & $65 \%$ & $85 \%$ & 26 & $77 \%$ & $80 \%$ & 48 & $58 \%$ & $89 \%$ \\
\hline Promotion & 82 & $73 \%$ & $83 \%$ & 26 & $100 \%$ & $78 \%$ & 56 & $61 \%$ & $82 \%$ \\
\hline Sample & 99 & $68 \%$ & $85 \%$ & 35 & $80 \%$ & $89 \%$ & 64 & $61 \%$ & $82 \%$ \\
\hline \multicolumn{10}{|c|}{ Behavioral Outcomes by Intervention Characteristic } \\
\hline \multirow[b]{2}{*}{ Coding category } & \multicolumn{3}{|c|}{ Overall } & \multicolumn{3}{|c|}{ Youth and Young Adults } & \multicolumn{3}{|c|}{ Other Populations } \\
\hline & $\mathbf{N}$ & $\begin{array}{c}\text { Percent Reported } \\
\text { Outcome }\end{array}$ & $\begin{array}{c}\text { Percent } \\
\text { Significant Effect }\end{array}$ & $\mathbf{N}$ & $\begin{array}{l}\text { Percent Reported } \\
\text { Outcome }\end{array}$ & $\begin{array}{c}\text { Percent } \\
\text { Significant Effect }\end{array}$ & $\mathbf{N}$ & $\begin{array}{l}\text { Percent Reported } \\
\text { Outcome }\end{array}$ & $\begin{array}{c}\text { Percent } \\
\text { Significant Effect }\end{array}$ \\
\hline \multicolumn{10}{|l|}{ Product Promoted } \\
\hline Male Condom & 80 & $68 \%$ & $82 \%$ & 30 & $73 \%$ & $68 \%$ & 50 & $64 \%$ & $91 \%$ \\
\hline Female Condom & 9 & $67 \%$ & $67 \%$ & 2 & $100 \%$ & $100 \%$ & 7 & $57 \%$ & $50 \%$ \\
\hline Both & 10 & $60 \%$ & $83 \%$ & 3 & $33 \%$ & $100 \%$ & 7 & $71 \%$ & $80 \%$ \\
\hline \multicolumn{10}{|l|}{ Year of Publication } \\
\hline 2000 to 2009 & 45 & $73 \%$ & $79 \%$ & 20 & $70 \%$ & $79 \%$ & 25 & $76 \%$ & $79 \%$ \\
\hline 2010 to 2019 & 54 & $61 \%$ & $82 \%$ & 15 & $73 \%$ & $64 \%$ & 39 & $56 \%$ & $91 \%$ \\
\hline Reported Mass Media Channels & 51 & $78 \%$ & $80 \%$ & 23 & $78 \%$ & $72 \%$ & 28 & $79 \%$ & $86 \%$ \\
\hline Scientific Theory Mentioned & 42 & $81 \%$ & $82 \%$ & 22 & $82 \%$ & $83 \%$ & 20 & $80 \%$ & $81 \%$ \\
\hline Formative Research Mentioned & 33 & $67 \%$ & $77 \%$ & 18 & $67 \%$ & $83 \%$ & 15 & $67 \%$ & $70 \%$ \\
\hline
\end{tabular}


Table 6. Cont

\begin{tabular}{|c|c|c|c|c|c|c|c|c|c|}
\hline \multicolumn{10}{|l|}{ Marketing $\mathrm{P}^{\prime} \mathrm{s}$} \\
\hline Product & 66 & $71 \%$ & $81 \%$ & 22 & $82 \%$ & $78 \%$ & 44 & $66 \%$ & $83 \%$ \\
\hline Price & 49 & $78 \%$ & $79 \%$ & 19 & $79 \%$ & $73 \%$ & 30 & $77 \%$ & $83 \%$ \\
\hline Place & 74 & $68 \%$ & $84 \%$ & 26 & $73 \%$ & $79 \%$ & 48 & $65 \%$ & $87 \%$ \\
\hline Promotion & 82 & $71 \%$ & $83 \%$ & 26 & $88 \%$ & $78 \%$ & 56 & $63 \%$ & $86 \%$ \\
\hline Sample & 99 & $67 \%$ & $85 \%$ & 35 & $71 \%$ & $76 \%$ & 64 & $64 \%$ & $84 \%$ \\
\hline \multicolumn{10}{|c|}{ Awareness Outcomes by Intervention Characteristics } \\
\hline \multirow[b]{2}{*}{ Coding category } & \multicolumn{3}{|c|}{ Overall } & \multicolumn{3}{|c|}{ Youth and Young Adults } & \multicolumn{3}{|c|}{ Other Populations } \\
\hline & $\mathbf{N}$ & $\begin{array}{c}\text { Percent Reported } \\
\text { Outcome }\end{array}$ & $\begin{array}{c}\text { Percent } \\
\text { Significant Effect }\end{array}$ & $\mathbf{N}$ & $\begin{array}{c}\text { Percent Reported } \\
\text { Outcome }\end{array}$ & $\begin{array}{c}\text { Percent } \\
\text { Significant Effect }\end{array}$ & $\mathbf{N}$ & $\begin{array}{l}\text { Percent Reported } \\
\text { Outcome }\end{array}$ & $\begin{array}{c}\text { Percent } \\
\text { Significant Effect }\end{array}$ \\
\hline \multicolumn{10}{|l|}{ Product Promoted } \\
\hline Male Condom & 80 & $51 \%$ & $68 \%$ & 30 & $50 \%$ & $47 \%$ & 50 & $52 \%$ & $81 \%$ \\
\hline Female Condom & 9 & $56 \%$ & $80 \%$ & 2 & $50 \%$ & $0 \%$ & 7 & $57 \%$ & $100 \%$ \\
\hline Both & 10 & $60 \%$ & $67 \%$ & 3 & $67 \%$ & $50 \%$ & 7 & $57 \%$ & $75 \%$ \\
\hline \multicolumn{10}{|l|}{ Year of Publication } \\
\hline 2000 to 2009 & 45 & $47 \%$ & $62 \%$ & 20 & $35 \%$ & $29 \%$ & 25 & $56 \%$ & $79 \%$ \\
\hline 2010 to 2019 & 54 & $57 \%$ & $74 \%$ & 15 & $73 \%$ & $55 \%$ & 39 & $51 \%$ & $85 \%$ \\
\hline Reported Mass Media Channels & 51 & $57 \%$ & $76 \%$ & 23 & $48 \%$ & $55 \%$ & 28 & $64 \%$ & $89 \%$ \\
\hline Scientific Theory Mentioned & 42 & $64 \%$ & $63 \%$ & 22 & $50 \%$ & $46 \%$ & 20 & $80 \%$ & $75 \%$ \\
\hline Formative Research Mentioned & 33 & $52 \%$ & $59 \%$ & 18 & $56 \%$ & $50 \%$ & 15 & $47 \%$ & $71 \%$ \\
\hline \multicolumn{10}{|l|}{ Marketing P's } \\
\hline Product & 66 & $62 \%$ & $73 \%$ & 22 & $55 \%$ & $50 \%$ & 44 & $66 \%$ & $83 \%$ \\
\hline Price & 49 & $63 \%$ & $74 \%$ & 19 & $53 \%$ & $50 \%$ & 30 & $70 \%$ & $86 \%$ \\
\hline Place & 74 & $57 \%$ & $74 \%$ & 26 & $54 \%$ & $50 \%$ & 48 & $58 \%$ & $86 \%$ \\
\hline Promotion & 82 & $55 \%$ & $71 \%$ & 26 & $65 \%$ & $47 \%$ & 56 & $50 \%$ & $86 \%$ \\
\hline Sample & 99 & $53 \%$ & $71 \%$ & 35 & $51 \%$ & $50 \%$ & 64 & $53 \%$ & $82 \%$ \\
\hline
\end{tabular}


Table 6. Cont

\begin{tabular}{|c|c|c|c|c|c|c|c|c|c|}
\hline \multirow[b]{3}{*}{ Coding category } & \multicolumn{6}{|c|}{ Sales outcomes by Intervention Characteristics } & & & \\
\hline & \multicolumn{3}{|c|}{ Overall } & \multicolumn{3}{|c|}{ Youth and Young Adults } & \multicolumn{3}{|c|}{ Other Populations } \\
\hline & $\mathbf{N}$ & $\begin{array}{l}\text { Percent Reported } \\
\text { Outcome }\end{array}$ & $\begin{array}{c}\text { Percent } \\
\text { Significant Effect }\end{array}$ & $\mathbf{N}$ & $\begin{array}{l}\text { Percent Reported } \\
\text { Outcome }\end{array}$ & $\begin{array}{c}\text { Percent } \\
\text { Significant Effect }\end{array}$ & $\mathbf{N}$ & $\begin{array}{c}\text { Percent Reported } \\
\text { Outcome }\end{array}$ & $\begin{array}{c}\text { Percent } \\
\text { Significant Effect }\end{array}$ \\
\hline \multicolumn{10}{|l|}{ Product Promoted } \\
\hline Male Condom & 80 & $25 \%$ & $90 \%$ & 30 & $13 \%$ & $100 \%$ & 50 & $32 \%$ & $88 \%$ \\
\hline Female Condom & 9 & $0 \%$ & NA & 2 & $0 \%$ & NA & 7 & $0 \%$ & NA \\
\hline Both & 10 & $40 \%$ & $100 \%$ & 3 & $33 \%$ & $100 \%$ & 7 & $43 \%$ & $100 \%$ \\
\hline \multicolumn{10}{|l|}{ Year of Publication } \\
\hline 2000 to 2009 & 45 & $16 \%$ & $86 \%$ & 20 & $10 \%$ & $100 \%$ & 25 & $20 \%$ & $67 \%$ \\
\hline 2010 to 2019 & 54 & $31 \%$ & $94 \%$ & 15 & $20 \%$ & $100 \%$ & 39 & $36 \%$ & $91 \%$ \\
\hline Reported Mass Media Channels & 51 & $22 \%$ & $100 \%$ & 23 & $17 \%$ & $100 \%$ & 28 & $25 \%$ & $100 \%$ \\
\hline Scientific Theory Mentioned & 42 & $12 \%$ & $80 \%$ & 22 & $5 \%$ & $100 \%$ & 20 & $20 \%$ & $75 \%$ \\
\hline Formative Research Mentioned & 33 & $12 \%$ & $75 \%$ & 18 & $11 \%$ & $100 \%$ & 15 & $13 \%$ & $50 \%$ \\
\hline \multicolumn{10}{|l|}{ Marketing P's } \\
\hline Product & 66 & $20 \%$ & $85 \%$ & 22 & $9 \%$ & $100 \%$ & 44 & $25 \%$ & $82 \%$ \\
\hline Price & 49 & $27 \%$ & $92 \%$ & 19 & $16 \%$ & $100 \%$ & 30 & $33 \%$ & $90 \%$ \\
\hline Place & 74 & $30 \%$ & $91 \%$ & 26 & $19 \%$ & $100 \%$ & 48 & $35 \%$ & $88 \%$ \\
\hline Promotion & 82 & $20 \%$ & $94 \%$ & 26 & $12 \%$ & $100 \%$ & 56 & $23 \%$ & $92 \%$ \\
\hline Sample & 99 & $24 \%$ & $96 \%$ & 35 & $14 \%$ & $100 \%$ & 64 & $30 \%$ & $90 \%$ \\
\hline
\end{tabular}




\section{Discussion}

Sustained demand generation that results in repeat, intensive exposure to behavior change messages tailored to diverse user needs remains a critical need in many countries. Decreasing funding for condom programming across many countries has weakened efforts to develop and deliver behavior change interventions of the scale and the intensity necessary to overcome barriers to condom use [23]. Significantly more investment in demand generation activities ranging from branded and generic mass media to highly targeted interpersonal communication (IPC) is needed to ensure that people-especially youth—have the knowledge, the skills, and the power to use condoms correctly and consistently.

Condom programs must ensure that there are adequate condom supplies and distribution systems to meet current and future user demand. Though some countries have made progress in securing sufficient funding for condom procurement and for increasing condom distribution through the public sector, under-served areas remain. Condom stock-outs at the facility level and condom wastage remain challenges. Procurement of condoms in excess of reasonable projections for growth in demand also contributes to condom wastage in some countries [24]. Efforts need to include adequate condom and lubricant procurement and supplies, community-based distribution to priority populations, and targeted distribution of free commodities for those with greatest need, especially in rural and isolated locations. Decreased funding for social marketing programs and low interest from the commercial sector in reaching beyond high value urban markets also contribute to access gaps.

This study demonstrates that condoms continue to be widely promoted worldwide and, given the epidemiology of HIV/STIs, they remain a crucial technology for preventing transmission. In 2017, UNAIDS estimated that 36.9 million people were living with the HIV virus with 1.8 million new infections, the majority through unprotected sexual intercourse [25]. In addition, every day, one million people are infected with curable STIs, while over 500 million are already affected with HSV2 and 300 million with HPV [26]. There is an urgent and, to a significant extent, unmet need for women and girls to have access to condoms and other contraceptives. Most of these issues are more dramatic in SSA and among young and vulnerable people. Given the "youth bulge" in SSA that is projected to continue until the mid-21st century, there will eventually be more young people age 15-24 in the region than in India or China [27], and related increases over time in the 25-34-year-old young adult cohort. In part, as a result of these demographic changes, estimates suggest that condom availability and use will represent the largest share of total HIV infections avoided by 2030 [27].

The importance of condom promotion is suggested in part by the significant body of research in the field, some 99 published studies using the restrictive inclusion criteria in this study, and the pace of studies increased in the decade from 2010-2019 (54 of 99 reviewed) despite recent reductions in condom donor spending. However, it is worth noting that the percentage of studies showing a significant effect on condom use dropped from $87 \%$ in $2000-2009$ to $78 \%$ in $2010-2019$. The latter may reflect an increase in interest in evaluation data to support continued expenditures on campaigns and justify specific approaches and population focus; however, at the same time, the effects of other prevention and treatment efforts, such as PrEP, influence consistent condom use [12].

This review confirmed our original $\mathrm{H} 1$ that condom promotion studies are effective in promoting determinants and condom use. Condom promotion studies demonstrated a high degree of effectiveness in promoting condom use and related behavioral outcomes, with $85 \%$ demonstrating positive effects in these areas. It is worth noting that a smaller percentage of studies demonstrated message awareness in specific promotions $(71 \%)$, indicating perhaps a need for better dosage/exposure measurement as well as sustained delivery of promotions.

Condom promotion studies that examined sales and distribution overwhelmingly reported an increase in sales or distribution (or both, 96\%), confirming H2. Large scale condom promotion efforts reached widespread populations, including those most in need in low and middle income countries that face a disproportionate burden of HIV/STI infections and unmet contraceptive needs. This was true even in the most recent years (since 2010), when donor funding for condom distribution and promotion has declined. 
Best practice marketing techniques were widely used in condom promotion, with the majority of studies employing multiple marketing channels and Ps from marketing theory. Additionally, a wide mix of marketing channels were used, and these were generally targeted to the media platforms most widely used in the country/region. In particular, there was widespread use of community outreach, radio, and outdoor advertising promotion. It is worth noting that relatively few studies used social media or other digital media to promote condoms, likely because they were often conducted in LMIC. However, this represents an opportunity to expand the reach and the recognition of condom promotion efforts.

In terms of RQ1 and whether condom promotion efforts have targeted or have been more effective among population groups such as AYA or in specific geographic locations and other settings, we made several findings. First, a disproportionate number (35 of 99) of condom promotion effort targeted AYA populations compared to other age sub-groups. Given that AYA are at greater risk, this is promising. However, it is worth noting that the majority of these AYA targeted efforts were in the US and Canada, and a disproportionately smaller number were in Sub-Saharan Africa, where condom promotion will be greatly needed in the coming decade and beyond.

We also observed greater use of mass media channels and greater use of behavior change theory in AYA condom promotion efforts compared to the overall sample. Thus, these efforts have potential to reach wider AYA audiences and are guided by solid conceptual foundations. We observed significant effects of AYA targeted efforts but overall not greater effects than on the overall sample. We did observe lower levels of effects on product awareness and positive reactions to promotions, but this may also reflect differences in media preferences and use. Given that we found very few efforts that utilized digital and social media, especially in the decade from 2010-2019, when such strategies become widespread in public health, this may reflect a need and an opportunity to shift condom promotion campaigns to the channels most used by AYA.

Overall, condom promotion efforts with AYA when specific outcomes of increasing positive attitudes, social norms, and beliefs as well as condom use behavior and sales/distribution were targeted were effective. This is promising, given that AYA are often hard to reach and at risk. This review suggests that condom promotion efforts are at least equally effective with AYA as with the overall sample of marketing promotions, and thus, considering the massive need for programs given rising AYA populations, such efforts deserve greater emphasis and attention.

There is a need for more research that sheds light on how best to build healthy markets (total market approach) for condoms [28,29]. More research is needed on how to successfully market condoms and encourage condom use using digital media marketing strategies that the youth and the young adult audience increasingly use in LMIC.

Despite its many strengths and new information yielded by this systematic review, the study has some limitations. First, promotion terminology is known to be difficult to identify in some cases due to inconsistent use of language in communication and marketing literature [30,31]. Second, we did not conduct a meta-analysis and thus cannot comment on the quality of actual data analysis or reporting of data in the reviewed papers. Finally, we acknowledge that there is substantial gray literature on communication and marketing campaigns in LMIC, and many condom promotion and distribution efforts are captured there and not in this study. For purposes of consistency and knowing the universe of articles to be screened, we elected to follow the PRISMA methodology and restrict our focus to peer-reviewed literature.

\section{Conclusions}

Despite advances in HIV treatments, including pre-exposure prophylaxis (PrEP), condoms remain an essential prevention method, especially in light of the tremendous demographic shifts in sub-Saharan Africa over the coming decade [15]. New priorities to ensure sufficient donor support for condom promotion programs are needed in the new environment for HIV/STI prevention. Condoms remain an essential strategy, and the evidence reviewed here shows that marketing promotions are effective in 
encouraging condom use behavior, sales, and distribution outcomes, and new intervention strategies utilizing digital media, the channel most widely used by priority populations such as AYA, should continue to be developed and evaluated.

Supplementary Materials: The following are available online at http:/www.mdpi.com/1660-4601/17/7/2262/s1, Table S1: Summary of Articles Reviewed [13,14,32-128].

Author Contributions: W.D.E. conceptualized the study, developed the search strategy, coded articles, collaborated on the analysis, and wrote the article. A.U. coded articles, conducted the analysis, and contributed to the article. M.H. assisted in initial article screening and creating tables. B.D. contributed to the article. All authors have read and agreed to the published version of the manuscript.

Funding: This project was sponsored by the United Nations Family Planning Agency

Conflicts of Interest: The authors declare that they have no conflict of interest with this study.

\section{References}

1. Evidence for Contraceptive Options and HIV Outcomes (ECHO). HIV incidence among women using intramuscular depot medroxyprogesterone acetate, a copper IUD, or a levonorgestrel implant for contraception: A randomised multicentre, open-label trial. Lancet 2019. [CrossRef]

2. UNAIDS. UNAIDS Data 2019. Available online: https://www.unaids.org/en/resources/documents/2019/2019UNAIDS-data (accessed on 20 January 2020).

3. Mann Global Health. Challenges and Recommendations for Reaching 'Fast Track' Targets for Condom Use. Available online: https://mannglobalhealth.com/what-we-do/reports/ (accessed on 19 January 2020).

4. Mann Global Health. Donor Funding Landscape for Condom Programming. Available online: https: //mannglobalhealth.com/what-we-do/reports/ (accessed on 20 January 2020).

5. Weller, S.; Davis, K. Condom effectiveness in reducing heterosexual HIV transmission. Cochrane Database Syst. Rev. 2002, 1, CD003255. [CrossRef] [PubMed]

6. Smith, D.; Herbst, J.A.; Zhang, X.; Rose, C.E. Condom efficacy by consistency of use among men who have sex with men. In Proceedings of the 20th Conference on Retroviruses and Opportunistic Infections (CROI 2013), Atlanta, GA, USA, 3-6 March 2013.

7. Johnson, W.D.; O'Leary, A.; Flores, S.A. Per-partner condom effectiveness against HIV for men who have sex with men. AIDS 2018, 32, 1499-1505. [CrossRef] [PubMed]

8. Trussell, J.; Sturgen, K.; Strickler, J.; Dominik, R. Comparative contraceptive efficacy of the female condom and other barrier methods. Fam. Plan. Perspect. 1994, 26, 66-72. [CrossRef]

9. Dehne, K.L.; Dallabetta, G.; Wilson, D. HIV prevention 2020: a framework for delivery and a call for action. Lancet 2016, 3, e323-e332. [CrossRef]

10. Mann Global Health. Condom Program Pathway. Available online: https://mannglobalhealth.com/wpcontent/uploads/2017/11/MGH_Condom-Landscaping-Report_Final_091117.pdf (accessed on 20 January 2020).

11. Gilson, L.; Lehmann, U.; Schneider, H. Practicing governance towards equity in health systems: LMIC perspectives and experience. Int. J. Equity Health 2017, 16, 171. [CrossRef]

12. Holt, M.; Newman, C.E.; Lancaster, K.; Smith, A.K.; Hughes, S.; Truong, H.-H.M. HIV pre-exposure prophylaxis and the 'problems' of reduced condom use and sexually transmitted infections in Australia: A critical analysis from an evidence-making intervention perspective. Sociol. Health Illn. 2019. [CrossRef]

13. Chapman, S.; Jafa, K.; Longfield, K.; Vielot, N.A.; Buszin, J.; Ngamkitpaiboon, L.; Kays, M. Condom social marketing in sub-Saharan Africa and the Total Market Approach. Sex. Health 2012, 9, 44-50. [CrossRef]

14. Evans, W.; Taruberekera, N.; Longfield, K.; Snider, J. Brand Equity and Willing to Pay for Condoms In Zimbabwe. Reprod. Health 2011, 8, 29. [CrossRef]

15. Canning, D.; Raja, S.; Yazbeck, A.S. Africa's Demographic Transition: Dividend or Disaster? Africa Development Forum Series; World Bank: Washington, DC, USA, 2015. [CrossRef]

16. Higgins, J.P.T.; Green, S. Cochrane Handbook for Systematic Reviews of Interventions; Version 5.1.0 [updated March 2011]; The Cochrane Collaboration: London, UK, 2011.

17. Evans, W.D.; Blitstein, J.; Hersey, J.; Renaud, J.; Yaroch, A. Systematic review of public health branding. J. Health Commun. 2008, 13, 721-741. [CrossRef] 
18. Snyder, L.B.; Hamilton, M.A.; Huedo-Medina, T. Does evaluation design impact communication campaign effect size? A meta-analysis. Commun. Methods Meas. 2009, 3, 84-104. [CrossRef]

19. Covey, J.; Rosenthal-Stott, H.E.S.; Howell, S.J. A synthesis of meta-analytic evidence of behavioral interventions to reduce HIV/STIs. J. Behav. Med. 2016, 39, 371-385. [CrossRef] [PubMed]

20. LaCroix, J.M.; Snyder, L.B.; Huedo-Medina, T.B.; Johnson, B.T. Effectiveness of mass media interventions for HIV prevention, 1986-2013: A meta-analysis. J. Acquir. Immune Defic. Syndr. 2014, 66, S329-S340. [CrossRef]

21. Moher, D.; Liberati, A.; Tetzlaff, J.; Altman, D.G.; The PRISMA Group. Preferred Reporting Items for Systematic Reviews and Meta-Analyses: The PRISMA Statement. PLoS Med. 2009, 6, e1000097. [CrossRef]

22. Kotler, P.; Lee, N. Social Marketing: Changing Behviors for Good, 4th ed.; Sage: Thousand Oaks, CA, USA, 2011.

23. Taruberekera, N.; Chatora, K.; Leuschner, S.; Munjoma, M.; Sithole, H.; Balasubramanian, S.; Jiyeong Park, F.; Rego, R.; Rowan, A.; Longfield, K. Strategic donor investments for strengthening condom markets: The case of Zimbabwe. PLoS ONE 2019, 14, e0221581. [CrossRef]

24. Beksinska, M.E.; Smit, J.A.; Mantell, J.E. Progress and challenges to male and female condom use in South Africa. Sex. Health 2012, 9, 51-58. [CrossRef]

25. Girum, T.; Wasie, A.; Worku, A. Trend of HIV/AIDS for the last 26 years and predicting achievement of the 90-90-90 HIV prevention targets by 2020 in Ethiopia: A time series analysis. BMC Infect Dis. 2018, 18, 320. [CrossRef] [PubMed]

26. Dwyer-Lindgren, L.; Cork, M.A.; Sligar, A.; Steuben, K.M.; Wilson, K.F.; Provost, N.R.; Mayala, B.K.; Vanderheide, J.D.; Collison, M.L.; Hall, J.B.; et al. Mapping HIV prevalence in sub-Saharan Africa between 2000 and 2017. Nature 2019, 570, 189-193. [CrossRef]

27. United Nations. World Population Prospects 2019. Available online: https://population.un.org/wpp/ Publications/Files/WPP2019_DataBooklet.pdf (accessed on 20 January 2020).

28. Evans, W.D.; Kadirov, K.; Thior, I.; Ganesan, R.; Ulasevich, A.; Deperthes, B. Willingness to Pay for Condoms among men in Sub-Saharan Africa. Int. J. Environ. Res. Public Health 2018, 16, 34. [CrossRef]

29. Brady, C.; Weeden, L.; Hutchings, J.; Parks, J. Planning Guide for a Total Market Approach to Increase Access to Family Planning. Module 1: Landscape Assessment; PATH: Seattle, WA, USA; The Population Council, Evidence Project: Washington, DC, USA, 2016.

30. McDermott, L.; Stead, M.; Hastings, G. What is and what is not social marketing. J. Mark. Manag. 2005, 21, 545-553. [CrossRef]

31. Evans, W.D.; Blistein, J.; Vallone, D.; Post, S.; Nielsen, W. Systematic review of health branding: Growth of a promising practice. Transl. Behav. Med. 2015, 5, 24-36. [CrossRef]

32. Adams, J.; Neville, S.; Parker, K.; Huckle, T. Influencing condom use by gay and bisexual men for anal sex through social marketing: A program evaluation of get it on!! Soc. Mark. Quart. 2017, 23, 3-17. [CrossRef]

33. Agha, S. An Evaluation of Adolescent Sexual Health Programs in Cameroon, Botswana, South Africa, and Guinea; Population Services International [PSI], Research Division: Washington, DC, USA, 2000.

34. Agha, S. Patterns of use of the female condom after one year of mass marketing. AIDS Educ. Prev. 2001, 13, 55-64. [CrossRef] [PubMed]

35. Agha, S. Intention to use the female condom following a mass-marketing campaign in Lusaka, Zambia. Am. J. Public Health 2001, 91, 307-310. [CrossRef] [PubMed]

36. Agha, S. The Impact of the Kenya Social Marketing Program on Personal Risk Perception, Perceived Self-Efficacy and on Other Behavioral Predictors; Population Services International PSI], Research Division: Washington, DC, USA, 2001.

37. Agha, S. A Quasi-Experimental Study to Assess the Impact of Four Adolescent Sexual Health Interventions in Sub-Saharan Africa. Int. Fam. Plan. Perspect. 2002, 28, 67-70. Available online: $\quad$ https://www.scopus.com/inward/record.uri?eid=2-s2.0-0036624275\&partnerID=40\&md5= 974615733e4916ccf11c7f95e2802fc3;https://www.scopus.com/inward/record.uri?eid=2-s2.0-0036624275\& partnerID=40\&md5=974615733e4916ccf11c7f95e2802fc3 (accessed on 11 February 2020). [CrossRef]

38. Agha, S.; Van Rossem, R. Impact of mass media campaigns on intentions to use the female condom in tanzania. Int. Fam. Plan. Perspect. 2002, 28, 151-158. [CrossRef]

39. Agha, S. The impact of a mass media campaign on personal risk perception, perceived self-efficacy and on other behavioural predictors. AIDS Care 2003, 15, 749-762. [CrossRef] 
40. Agha, S.; Karlyn, A.; Meekers, D. The promotion of condom use in non-regular sexual partnerships in urban mozambique. Health Policy Plan. 2001, 16, 144-151. Available online: https://www.scopus.com/inward/ record.uri?eid=2-s2.0-0035018955\&partnerID=40\&md5=f2a3c0864010c13eb6811feacdc8650b (accessed on 11 February 2020). [CrossRef]

41. Agha, S.; Meekers, D. Impact of an advertising campaign on condom use in urban pakistan. Stud. Fam. Plan. 2010, 41, 277-290. [CrossRef]

42. Agha, S.; Beaudoin, C.E. Assessing a thematic condom advertising campaign on condom use in urban pakistan. J. Health Commun. 2012, 17, 601-623. [CrossRef]

43. Artz, L.; Macaluso, M.; Kelaghan, J.; Austin, H.; Fleenor, M.; Robey, L.; Hook, E.W.; Brill, I. An intervention to promote the female condom to sexually transmitted disease clinic patients. Behav. Modif. 2005, 29, 318-369. [CrossRef] [PubMed]

44. Ashraf, N.; Bandiera, O.; Jack, B.K. No margin, no mission? A field experiment on incentives for public service delivery. J. Public Econ. 2014, 120, 1-17. [CrossRef]

45. Aung, T.; Thet, M.M.; Sudhinaraset, M.; Diamond-Smith, N. Impact of a social franchise intervention program on the adoption of long and short acting family planning methods in hard to reach communities in myanmar. J. Public Health (Oxf. Engl.) 2019, 41, 192-200. [CrossRef] [PubMed]

46. Basu, I.; Jana, S.; Rotheram-Borus, M.; Swendeman, D.; Lee, S.; Newman, P.; Weiss, R. HIV prevention among sex workers in india. JAIDS J. Acquir. Immune Defic. Syndr. 2004, 36, 845-852. [CrossRef] [PubMed]

47. Benzaken, A.S.; Garcia, E.G.; Gomes Sardinha, J.C.; Pedrosa, V.L.; Paiva, V. Community-based intervention to control STD/AIDS in the amazon region, Brazil. Rev. Saude Publica 2007, 41, 2.

48. Bhaskar, R.S. Impact of a behaviour change intervention model for promotion of condoms amongst young adult males in an occupational setting. Med. J. Armed Forces India 2012, 68, 316-321. [CrossRef]

49. Brent, R. A cost-benefit analysis of a condom social marketing programme in tanzania. Appl. Econ. 2009, 41, 497-509. [CrossRef]

50. Brown, B. At nicaraguan motels rented for sexual encounters, making condoms available in rooms increases use. Int. Fam. Plan. Perspect. 2000, 26, 201-202. Available online: http://www.guttmacher.org/pubs/journals/ 2620100.html (accessed on 26 March 2020). [CrossRef]

51. Bull, S.S.; Cohen, J.; Ortiz, C.; Evans, T. The POWER campaign for promotion of female and male condoms: Audience research and campaign development. Health Commun. 2002, 14, 475-491. [CrossRef]

52. Bull, S.S.; Posner, S.F.; Ortiz, C.; Beaty, B.; Benton, K.; Lin, L.; Pals, S.L.; Evans, T. POWER for reproductive health: Results from a social marketing campaign promoting female and male condoms. J. Adolesc. Health 2008, 43, 71-78. [CrossRef]

53. Bull, S.S.; Levine, D.K.; Black, S.R.; Schmiege, S.J.; Santelli, J. Social media-delivered sexual health intervention: A cluster randomized controlled trial. Am. J. Prev. Med. 2012, 43, 467-474. [CrossRef] [PubMed]

54. Bulsara, A.L. Social Marketing for Adolescent Sexual Health: Results of Operations Research Projects in Botswana, Cameroon, Guinea, and South Africa; Population Services International PSI: Washington, DC, USA, 2000; Available online: http://www.prb.org/pdf/SocialMarketAdolesc_Eng.pdf (accessed on 26 March 2020).

55. Burke, R.C.; Wilson, J.; Bernstein, K.T.; Grosskopf, N.; Murrill, C.; Cutler, B.; Sweeney, M.; Begier, E.M. The NYC condom: Use and acceptability of new york city's branded condom. Am. J. Public Health 2009, 99. [CrossRef] [PubMed]

56. Burke, R.C.; Wilson, J.; Kowalski, A.; Murrill, C.; Cutler, B.; Sweeney, M.; Begier, E.M. NYC condom use and satisfaction and demand for alternative condom products in new york city sexually transmitted disease clinics. J. Urban Health Bull. N. Y. Acad. Med. 2011, 88, 749-758. [CrossRef] [PubMed]

57. Cerdeño, A.F.; Martinez-Donate, A.P.; Zellner, J.; Sañudo, F.; Carrillo, H.; Engelberg, M.; Sipan, C.L.; Hovell, M. Marketing HIV prevention for heterosexually identified latino men who have sex with men and women: The hombres sanos campaign. J. Health Commun. 2012, 17, 641-658. [CrossRef] [PubMed]

58. Cheng, H.D. Promoting contraceptive use more effectively among unmarried male migrants in construction sites in china: A pilot intervention trial. Asia Pac. J. Public Health 2012, 24, 806-815. [CrossRef]

59. Chiang, K.-P.; Chan, A.; Milan, R. Social marketing and advertising appeals: On perception and intention to purchase condoms among college students. Int. J. Healthc. Manag. 2018, 11, 71-78. [CrossRef]

60. Crosby, R.; DiClemente, R.J.; Charnigo, R.; Snow, G.; Troutman, A. A brief, clinic-based, safer sex intervention for heterosexual african american men newly diagnosed with an STD: A randomized controlled trial. Am. J. Public Health 2009, 99 (Suppl. 1), S96-S103. [CrossRef] 
61. Darden, C. Promoting condoms in brazil to men who have sex with men. Reprod. Health Matters 2006, 14, 63-67. [CrossRef]

62. Davis, K.C.; Uhrig, J.; Bann, C.; Rupert, D.; Fraze, J. Exploring african american women's perceptions of a social marketing campaign to promote HIV testing. Soc. Mark. Quart. 2011, 17, 39-60. [CrossRef]

63. Jarlais, D.C.D.; McKnight, C.; Arasteh, K.; Feelemyer, J.; Perlman, D.; Hagan, H.; Cooper, H.L.F. Use of the "nYC condom" among people who use drugs. J. Urban Health 2014, 91, 547-554. [CrossRef]

64. Jarlais, D.C.D.; Arastéh, K.; McKnight, C.; Feelemyer, J.; Hagan, H.; Cooper, H.L.F.; Perlman, D.C. Combined HIV prevention, the new york city condom distribution program, and the evolution of safer sex behavior among persons who inject drugs in new york city. AIDS Behav. 2014, 18, 443-451. [CrossRef] [PubMed]

65. Martinez-Donate, A.P.; Zellner, J.; Sañudo, F.; Fernández-Cerdeño, A.; Hovell, M.F.; Sipan, C.L.; Engelberg, M.; Carrillo, H. Hombres sanos: Evaluation of a social marketing campaign for heterosexually identified latino men who have sex with men and women. Am. J. Public Health 2010, 100, 2532-2540. [CrossRef] [PubMed]

66. Drake, J.K.; Thi Thanh, L.H.; Suraratdecha, C.; Thi Thu, H.P.; Vail, J.G. Stakeholder perceptions of a total market approach to family planning in Vietnam. Reprod. Health Matters 2010, 18, 46-55. [CrossRef]

67. Drake, J.K.; Espinoza, H.; Suraratdecha, C.; Lacayo, Y.; Keith, B.M.; Vail, J.G. Stakeholder perceptions of a total market approach to family planning in nicaragua. Rev. Panam. Salud Publica Pan Am. J. Public Health 2011, 29, 329-336. Available online: https://www.scopus.com/inward/record.uri?eid=2-s2.0-79959992214\& partnerID=40\&md5=c60853605320f2b1a2fbbc41bdf0b266 (accessed on 11 February 2020).

68. Eloundou-Enyegue, P.; Meekers, D.; CalvÃ $*$ s, A.E. From awareness to adoption: The effect of aids education and condom social marketing on condom use in tanzania (1993-1996). J. Biosoc. Sci. 2005, 37, 257-268. [CrossRef]

69. Evans, W.D.; Longfield, K.; Shekhar, N.; Rabemanatsoa, A.; Reerink, I.; Snider, J. Social Marketing and Condom Promotion in Madagascar: A Case Study in Brand Equity Research. In The Handbook of Global Health Communication; Obregon, R., Waisbord, S., Eds.; Wiley-Blackwell: New York, NY, USA, 2012; pp. 330-347. [CrossRef]

70. Farris, K.B.; Aquilino, M.L.; Batra, P.; Marshall, V.; Losch, M.E. Impact of a passive social marketing intervention in community pharmacies on oral contraceptive and condom sales: A quasi-experimental study. BMC Public Health 2015, 15. [CrossRef]

71. Flowers, P.; McDaid, L.M.; Knussen, C. Exposure and impact of a mass media campaign targeting sexual health amongst scottish men who have sex with men: An outcome evaluation. BMC Public Health 2013, 13. [CrossRef]

72. Fontu, A. Exploring the impact of social marketing of female condoms in the city of kumba, cameroon. 2010-2011. Aids Res. Hum. Retrovir. 2014, 30, A199-A200. [CrossRef]

73. Geibel, S.; King'ola, N.; Temmerman, M.; Luchters, S. The impact of peer outreach on HIV knowledge and prevention behaviours of male sex workers in mombasa, kenya. Sex. Transm. Infect. 2012, 88, 357-362. [CrossRef]

74. Ganesan, R. Assessment of the Retail Environment of Male Condoms in Kenya, Nigeria, South Africa, Zambia, and zimbabwearlington, Virginia, JSI Research and Training Institute, Strengthening High Impact Interventions for an AIDS-Free Generation AIDSFree. 2017. Available online: https://aidsfree.usaid.gov/ sites/default/files/2017.10.25_af-retail-env-condoms-rep.pdf (accessed on 26 March 2020).

75. Grey, M.N. Central american sex workers' introduction of the female condom to different types of sexual partners. AIDS Educ. Prev. 2010, 22, 466-481. [CrossRef]

76. Kennedy, S.; Harris, A.; Jubwe, S.; Taylor, C.; Martin, R.; Bee, E.; Perry, O.; Massaquoi, M.; Woods, D.; Barbu, E. Condom Social Marketing Program to Prevent HIV/AIDS in Postconflict Liberia. Afr. Health Sci. 2011, 11, S81. Available online: https://www.scopus.com/inward/record.uri?eid=2-s2.0-80053639632\& partnerID=40\&md5=650603365096c32a6f812ec99ece39e2;https://www.scopus.com/inward/record.uri?eid= 2-s2.0-80053639632\&partnerID $=40 \&$ md5 $=650603365096 c 32 a 6 f 812$ ec99ece39e2 (accessed on 11 February 2020). [CrossRef] [PubMed]

77. Hernandez, J.H.; Akilimali, P.Z.; Muanda, M.F.; Glover, A.L.; Bertrand, J.T. Evolution of a large-scale community-based contraceptive distribution program in kinshasa, DRC based on process evaluation. Glob. Health Sci. Pract. 2018, 6, 657-667. [CrossRef] [PubMed]

78. Hill, C.A.; Abraham, C. School-based, randomised controlled trial of an evidence-based condom promotion leaflet. Psychol. Health 2008, 23, 41-56. [CrossRef] [PubMed] 
79. Hoke, T.H.; Feldblum, P.J.; Van Damme, K.; Nasution, M.D.; Grey, T.W.; Wong, E.L.; Ralimamonjy, L.; Raharimalala, L.; Rasamindrakotroka, A. Randomised controlled trial of alternative male and female condom promotion strategies targeting sex workers in madagascar. Sex. Transm. Infect. 2007, 83, 448-453. [CrossRef]

80. Joanis, C.; Beksinska, M.; Hart, C.; Tweedy, K.; Linda, J.; Smit, J. Three new female condoms: Which do south-african women prefer? Contraception 2011, 83, 248-254. [CrossRef]

81. Katende, B.R. Multi-media campaign exposure effects on knowledge and use of condoms for STI and HIV/AIDS prevention in uganda. Eval. Program Plan. 2004, 27, 397-407.

82. Kennedy, M.G.; Mizuno, Y.; Seals, B.F.; Myllyluoma, J.; Weeks-Norton, K. Increasing condom use among adolescents with coalition-based social marketing. Aids 2000, 14, 1809-1818. [CrossRef]

83. Kennedy, S.B.; Nolen, S.; Pan, Z.; Smith, B.; Applewhite, J.; Vanderhoff, K.J. Effectiveness of a brief condom promotion program in reducing risky sexual behaviours among african american men. J. Eval. Clin. Pract. 2013, 19, 408-413. [CrossRef]

84. Liao, N.L. Promoting female condoms in the sex industry in 4 towns of southern china: Context matters. Sex. Transm. Dis. 2013, 40, 264-270. [CrossRef]

85. Lin, Y.J.; Lee, C.H.; Chang, C.C.; Lin, C.H. Evaluation of a video-based intervention to promote condom use among college students in taiwan. Stud. Health Technol. Inform. 2016, 226, 101-104.

86. Longfield, K.; Panyanouvong, X.; Chen, J.; Kays, M.B. Increasing safer sexual behavior among lao kathoy through an integrated social marketing approach. BMC Public Health 2011, 11. [CrossRef] [PubMed]

87. Lugada, E.S.; Millar, D.; Haskew, J.; Grabowsky, M.; Garg, N.; Vestergaard, M.; Kahn, J.; Muraguri, N.; Mermin, J. Rapid implementation of an integrated large-scale HIV counseling and testing, malaria, and diarrhea prevention campaign in rural kenya. PLoS ONE 2010, 5, e12435. [CrossRef]

88. Martinez-Donate, A.P.; Zellner, J.; Fernández-Cerdeño, A.; Sañudo, F.; Hovell, M.F.; Sipan, C.L.; Engelberg, M.; Ji, M. Hombres sanos: Exposure and response to a social marketing hiv prevention campaign targeting heterosexually identified latino men who have sex with men and women. Aids Educ. Prev. 2009, 21, 124-136. [CrossRef]

89. McBride, S.D. A tailored minimal self-help intervention to promote condom use in young women: Results from a randomized trial. Aids 2003, 17, 1547-1556.

90. McCool-Myers, M. Implementing condom distribution programs in the United States: Qualitative insights from program planners. Eval. Program Plan. 2019, 74, 20-26. [CrossRef]

91. Meekers, D. Going underground and going after women: Trends in sexual risk behaviour among gold miners in South Africa. Int. J. STD AIDS 2000, 11, 21-26. [CrossRef]

92. Meekers, D. The effectiveness of targeted social marketing to promote adolescent reproductive health: The case of Soweto, South Africa. J. HIV/AIDS Prev. Educ. Adolesc. Child. 2000, 3, 73-92. [CrossRef]

93. Meekers, D.; Richter, K. Factors associated with use of the female condom in Zimbabwe. Int. Fam. Plan. Perspect. 2005, 31, 30-37. [CrossRef]

94. Meekers, D.; Agha, S.; Klein, M. The impact on condom use of the "100\% jeune" social marketing program in Cameroon. J. Adolesc. Health 2005, 36, 530.e12. [CrossRef]

95. Van, M.D. Using Behavior Change Communications to Overcome Social Marketing Sales Plateaus. Case Studies of Nigeria and India; Emerging Markets Group, Commercial Market Strategies: Washington, DC, USA, 2004; Available online: http://shopsproject.org/sites/default/files/resources/910_file_07_Nigeria_and_India_ Behavior_Change_Communications.pdf (accessed on 11 February 2020).

96. Van, M.D. The Reach and Impact of Social Marketing and Reproductive Health Communication Campaigns in Zambia; Carolina Population Center CPC, Measure Evaluation, University of North Carolina at Chapel Hill: Chapel Hill, NC, USA, 2004; Available online: http://www.cpc.unc.edu/measure/publications/pdf/wp-04-77.pdf (accessed on 26 March 2020).

97. Morris, C.N.; Morris, S.R.; Ferguson, A.G. Sexual behavior of female sex workers and access to condoms in kenya and uganda on the trans-africa highway. Aids and Behav. 2009, 13, 860-865. [CrossRef]

98. Piot, B.; Mukherjee, A.; Navin, D.; Krishnan, N.; Bhardwaj, A.; Sharma, V.; Marjara, P. Lot quality assurance sampling for monitoring coverage and quality of a targeted condom social marketing programme in traditional and non-traditional outlets in india. Sex. Transm. Infect. 2010, 86, 56-61. [CrossRef] [PubMed]

99. Plautz, A.; Meekers, D. Evaluation of the reach and impact of the $100 \%$ jeune youth social marketing program in Cameroon: Findings from three cross-sectional surveys. Reprod. Health 2007, 4. [CrossRef] [PubMed] 
100. Porto, M.P. Fighting AIDS among adolescent women: Effects of a public communication campaign in Brazil. J. Health Commun. 2007, 12, 121-132. [CrossRef] [PubMed]

101. Potter, W.; de Villemeur, M. Clinical breakage, slippage and acceptability of a new commercial polyurethane condom: A randomized, controlled study. Contraception 2003, 68, 39-45. [CrossRef]

102. Purdy, C.H. Fruity, fun and safe: Creating a youth condom brand in Indonesia. Reprod. Health Matters 2006, 14, 127-134. [CrossRef]

103. Purdy, C.H. Using the internet and social media to promote condom use in turkey. Reprod. Health Matters 2011, 19, 157-165. [CrossRef]

104. Rachakulla, H.K.; Venkaiah, K.; Rajkumar, H.; Prasad, S.; Kallam, S.; Goswami, P.; Dale, J.; Adhikary, R.; Paranjape, R.; Brahmam, G.N.V. Condom use and prevalence of syphilis and HIV among female sex workers in Andhra Pradesh, India-Following a large-scale HIV prevention intervention. BMC Public Health 2011, 11. [CrossRef]

105. Ramanathan, S.; Deshpande, S.; Gautam, A.; Pardeshi, D.B.; Ramakrishnan, L.; Goswami, P.; Adhikary, R.; George, B.; Paranjape, R.S.; Mainkar, M.M. Increase in condom use and decline in prevalence of sexually transmitted infections among high-risk men who have sex with men and transgender persons in Maharashtra, India: AVAHAN, the India AIDS initiative. BMC Public Health 2014, 14. [CrossRef]

106. Renaud, T.C.; Bocour, A.; Irvine, M.K.; Bernstein, K.T.; Begier, E.M.; Sepkowitz, K.A.; Kellerman, S.E.; Weglein, D. The free condom initiative: Promoting condom availability and use in New York City. Public Health Rep. 2009, 124, 481-489. [CrossRef]

107. Ridlo, I.A.; Zein, R.A. \#CondomEmoji: Are urban Indonesians receptive to a social media-based campaign for safer sex? Health Educ. 2018, 118, 386-401. [CrossRef]

108. Robinson, B.E.; Uhl, G.; Miner, M.; Bockting, W.O.; Scheltema, K.E.; Rosser, B.R.S.; Westover, B. Evaluation of a Sexual Health Approach to Prevent HIV among Low Income, Urban, Primarily African American Women: Results of a Randomized Controlled Trial. AIDS Educ. Prev. 2002, 14, 81-96. Available online: https://www.scopus.com/inward/record.uri?eid=2-s2.0-0035987819\&partnerID=40\&md5= 90641036f45681fd954398267c6e7ec4 (accessed on 11 February 2020). [CrossRef] [PubMed]

109. Rovniak, L.S.; Hovell, M.F.; Hofstetter, C.R.; Blumberg, E.J.; Sipan, C.L.; Batista, M.F.; Martinez-Donate, A.P.; Mulvihill, M.M.; Ayala, G.X. Engaging community businesses in human immunodeficiency virus prevention: A feasibility study. Am. J. Health Promot. 2010, 24, 347-353. [CrossRef] [PubMed]

110. Ryder, H.; Aspden, T.; Sheridan, J. The hawke's bay condom card scheme: A qualitative study of the views of service providers on increased, discreet access for youth to free condoms. Int. J. Pharm. Pract. 2015, 23, 381-389. [CrossRef]

111. Sharma, V.; Saggurti, N.; Bharat, S. Association between system reach and exposure to interventions and characteristics of mobile female sex workers in four high HIV prevalence states in India. Glob. J. Health Sci. 2015, 7, 83-95. [CrossRef] [PubMed]

112. Sales, J.M.; Brown, J.L.; Diclemente, R.J.; Rose, E. Exploring factors associated with nonchange in condom use behavior following participation in an STI/HIV prevention intervention for African-American adolescent females. AIDS Res. Treat. 2012. [CrossRef] [PubMed]

113. Scott-Sheldon, L.; Glasford, D.E.; Marsh, K.L.; Lust, S.A. Barriers to condom purchasing: Effects of product positioning on reactions to condoms. Soc. Sci. Med. 2006, 63, 2755-2769. [CrossRef]

114. Seidenfeld, D. An intervention to increase the condom supply in rural Zambia. Stud. Fam. Plan. 2014, 45, 379-387. [CrossRef]

115. Seoane Pascual, L. Qualitative Assessment of a Campaign Promoting Condom Use among a Teenage and Young Adult Population in the Community of Madrid, Spain. Rev. Esp. Salud Publica 2002, 76, 509-516. Available online: https://www.scopus.com/inward/record.uri?eid=2-s2.0-0036709452\&partnerID=40\&md5= 41f63bb9d9f6797af347d52194d04707;https://www.scopus.com/inward/record.uri?eid=2-s2.0-0036709452\& partnerID=40\&md5=41f63bb9d9f6797af347d52194d04707 (accessed on 26 March 2020). [CrossRef]

116. Sewak, A.; Singh, G. Assessment of the fiji-based condom social marketing (CSM) program. Sex. Cult. 2012, 16, 389-407. [CrossRef]

117. Sharma, V.; Saggurti, N.; Bharat, S. Health care coverage among long-distance truckers in India: An evaluation based on the tanahashi model. HIV Aids Research Palliat. Care 2015, 7, 83-94. [CrossRef]

118. Sood, S.; Nambiar, D. Comparative cost-effectiveness of the components of a behavior change communication campaign on HIV/AIDS in north India. J. Health Commun. 2006, 11, 143-162. [CrossRef] [PubMed] 
119. Tan, J.; Cai, R.; Lu, Z.; Cheng, J.; De Vlas, S.J.; Richardus, J.H. Joint marketing as a framework for targeting men who have sex with men in china: A pilot intervention study. AIDS Educ. Prev. 2013, 25, 102-111. [CrossRef] [PubMed]

120. Terris-Prestholt, F.; Windmeijer, F. How to sell a condom? the impact of demand creation tools on male and female condom sales in resource limited settings. J. Health Econ. 2016, 48, 107-120. [CrossRef] [PubMed]

121. Tomnay, J.E.; Hatch, B. Council-supported condom vending machines: Are they acceptable to rural communities? Sex. Health 2013, 10, 465-466. [CrossRef]

122. Tran, B.R.; Thomas, A.G.; Vaida, F.; Ditsela, M.; Phetogo, R.; Kelapile, D.; Haubrich, R.; Chambers, C.D.; Shaffer, R. An intervention study examining the effects of condom wrapper graphics and scent on condom use in the botswana defence force. AIDS Care Psychol. Socio Med. Asp. AIDS/HIV 2014, 26, 890-898. [CrossRef]

123. Uhrig, J.D.; Bann, C.M.; Wasserman, J.; Guenther-Grey, C.; EroÇ§lu, D. Audience reactions and receptivity to HIV prevention message concepts for people living with HIV. AIDS Educ. Prev. 2010, 22, 110-125. [CrossRef]

124. Van, A.S. The Impact of Mass Media Campaigns on Intentions to Use the Female Condom in Tanzania; Population Services International PSI, Research Division: Washington, DC, USA, 2001.

125. Van Rossem, R.; Meekers, D. An Evaluation of the Effectiveness of Targeted Social Marketing to Promote Adolescent and Young Adult Reproductive Health in Cameroon. AIDS Educ. Prev. 2000, 12, 383-404. Available online: https://www.scopus.com/inward/record.uri?eid=2-s2.0-0033766275\&partnerID=40\&md5= e9b17efc487dbe2dd880bbd390b1f56e (accessed on 11 February 2020).

126. Weigold, T.D. AIDS public service announcements: Effects of fear and repetition on predictors of condom use. Health Mark. Quart. 2001, 18, 39-61.

127. Williams, J.L.; Christensen, C.J.; Cagle, H.H.; Homan, C.E. Brief report on the effect of providing single versus assorted brand name condoms to hospital patients: A descriptive study. BMC Public Health 2001, 1, 1-4. [CrossRef]

128. Young, T.M.; Marks, M.J.; Zaikman, Y.; Zeiber, J.A. Situational influences on condom purchasing. Sex. Cult. 2017, 21, 925-941. [CrossRef]

(C) 2020 by the authors. Licensee MDPI, Basel, Switzerland. This article is an open access article distributed under the terms and conditions of the Creative Commons Attribution (CC BY) license (http://creativecommons.org/licenses/by/4.0/). 